\title{
Bariatrik Cerrahide Beslenme Yönetimi
}

\author{
Nutritional Management in Bariatric Surgery
}

\section{Şeyda Güngör ${ }^{1}$}

Geliş tarihi/Received: 09.10.2019 • Kabul tarihi/Accepted: 30.12.2019

\section{ÖZET}

Obezite vücutta sağlığı bozabilecek derecede anormal ve aşırı yağ birikimi olarak tanımlanır. Kronik ve kompleks bir hastalık olan obezitenin prevalansı Türkiye ve dünya genelinde giderek artmaktadır. Obezitenin çevresel, genetik, hormonal, metabolik veya farmakolojik pek çok nedeni bulunmaktadır. Obezitenin tedavisi medikal ve cerrahi tedavi olmak üzere ikiye ayrılmaktadır. Medikal tedavi fiziksel aktivite eşliğinde, yaşam biçimi değişiklikleri hedefleyen sürdürülebilir diyet tedavilerini ve farmakolojik tedavileri içermektedir. Medikal tedavinin sonuç vermediği durumlarda bariatrik cerrahiye başvurulmaktadır. Bariatrik cerrahinin, malabsorbtif, restriktif veya kombine yöntemleri mevcuttur. Operasyonların başarısına postoperatif dönemde hastaların fazla olan vücut ağırlı̆̆ındaki kayıp oranına bakılarak karar verilmektedir. Bariatrik cerrahinin mortalite oranı yaklaşık \%1 olarak bildirilmektedir. Preoperatif dönemde genel bir uygulama olarak komplikasyon riskini en aza indirmek amacıyla vücut ağırlı̆̆ı kaybı sağlanmaya çalışılmaktadır. Postoperatif dönemde ise hastalara ilk günden birkaç aya kadar yoğunluğu giderek artan diyetler uygulanmaktadır. Cerrahi sonrası kısa dönem komplikasyonları arasında bulantı, kusma, dehidratasyon, diyare, konstipasyon, besin intoleransı ve dumping senromu bulunmaktadır. Uzun dönem komplikasyonları olarak ise mikro ve makro besin ögesi yetersizlikleri gösterilmektedir. Perioperatif dönemde komplikasyon risklerinin önüne geçmek ve operasyon başarısını en üst seviyede tutmak için diyetisyenler tarafından hastaya uygun tıbbi beslenme tedavisinin planlanması ve hastaların beslenme takibinin dikkatle yapılması son derece önemlidir. Bu çalışmada bariatrik cerrahi sürecindeki beslenme ilkeleri hakkında literatür bilgisi derlenmiştir.

Anahtar kelimeler: Obezite, bariatrik cerrahi, perioperatif beslenme

\section{ABSTRACT}

Obesity is defined as abnormal and excessive fat accumulation that can impair health in the body. The prevalence of obesity which is a chronic and complex disease, is increasing in Turkey and worldwide. There are many causes of obesity such as environmental, genetic, hormonal, metabolic or pharmacological. Treatment of obesity is divided into two as medical and surgical. Medical treatment includes sustainable diet treatments that target lifestyle changes, accompanied by physical activity and pharmacological treatments. In cases where medical treatment does not work, bariatric surgery is applied. Bariatric surgery has malabsorptive, restrictive or combined methods. The success of the operations is decided in the postoperative period according to the loss rate of the patients' excess body weight. Mortality rate of bariatric surgery is reported to be approximately $1 \%$. As a general practice in the preoperative period, body weight loss is tried to be achieved in order to minimize the risk of complications. Diets with increasing intensity are applied to patients from the first day to several months in the postoperative period. Short-term complications after surgery include nausea, vomiting, dehydration,

1. İletişim/Correspondence: Muş Alparslan Üniversitesi Külliyesi, Sağllk Yüksekokulu, Beslenme ve Diyetetik Bölümü, Muş, Türkiye

E-posta: s.gungor @alparslan.edu.tr • ○ https://orcid.org/0000-0003-0333-8966 
diarrhea, constipation, nutrient intolerance and dumping syndrome. As long term complications, micro and macro nutrient deficiencies are shown. In order to prevent complication risks in the perioperative period and to keep to operation success at the highest level, it is extremely important to plan appropriate medical nutrition therapy and to follow the patients' nutrition carefully by the dietitians. In this study, literature information about nutritional principles in bariatric surgery was reviewed.

Keywords: Obesity, bariatric surgery, perioperative nutrition

\section{Gíriş}

Obezite, temelde enerji alımı ve harcanması arasındaki dengesizlikten kaynaklanan ve prevelansı dünya genelinde giderek artmakta olan ciddi ve kronik bir hastalıktır (1,2). Ülkemizde her 5 yılda bir güncellenen Türkiye Nüfus ve Sağlık Araştırması (TNSA) raporlarına göre; 15-49 yaş arası kadınların BKI değerlerinin 1998 yllından günümüze doğru giderek arttığı görülmüştür (2). Türkiye Beslenme ve Sağllk Araştırması (TBSA)-2010 sonuçlarına göre, Türkiye'de 19 yaş ve üzeri bireylerin \%30.3'ü obezdir. Cinsiyete göre değerlendirildiğinde ise kadınların \%41'i obez ve \%29.7'si fazla kilolu iken; erkeklerin \%20.5'i obez ve \%39.1’i fazla kilolu olarak tespit edilmiştir (3). Dünya Sağlık Örgütü (WHO); 2016 yılında dünya genelinde 18 yaş ve üzeri erkek ve kadınların \%39'unun fazla kilolu; erkeklerin \%11'inin kadınlarm ise \%15'inin obez olduğunu bildirmiştir. Bu verilere göre aynı yıl dünya genelinde 2 milyardan fazla yetişkinin fazla kilolu, yarım milyardan fazla yetişkinin obez olduğu bilinmektedir (4).

Obezitenin tedavisinde tubbi beslenme tedavisi önemli rol oynamaktadır. Tıbbi beslenme tedavisi ile davranış değişikliği tedavisinin sonuç vermediği ve farmakolojik tedavide sonuç alınamadığı durumlarda çeşitli bariatrik cerrahi tedavileri uygulanabilmektedir (1,5,6). Bariatrik cerrahi tedavisinin, besin ögesi emilimini engelleyici malabsorbtif, besin alımını kısıtlayıcı restriktif veya her ikisinin birlikte olduğu kombine yöntemleri bulunmaktadır (7). Bariatrik cerrahiye bağlı kısa ve uzun dönemde bazı komplikasyonların sık görüldüğü ve bariatrik cerrahi ile ilişkili mortalite oranının yaklaşık \%1 olduğu bildirilmektedir (8). Bu süreçte olası komplikasyonların önüne geçmek ve hastaların yaşam kalitelerini artırmak için hastaların sağlıklı beslenme programının diyetisyenler tarafindan oluşturulması ve beslenme takiplerinin yapılması son derece önemlidir.

$\mathrm{Bu}$ makalede bariatrik cerrahi sürecinde hastaların beslenme yönetimine ilişkin güncel, ulusal ve uluslararası bilgiler derlenmiştir.

\section{Obezite}

Obezitevücuttasağlığınıbozabilecekderecedeanormal veya aşırı yağ birikimi olarak tanımlanmaktadır (1). Yetişkinlerde zayıflık, fazla kiloluluk ve obezitenin sınıflandırılmasında basit bir boy-ağırlık indeksi olan Beden Kütle İndeksi (BKİ) kullanılmaktadır. BKİ vücut metrekaresi başına düşen ağırlığı kg cinsinden ifade etmektedir. Dünya Sağlık Örgütü’nün (WHO) 1995, 2000, 2004 verilerinden uyarlanmış olan BKI sınıflandırılması Tablo 1'de gösterilmiştir (9). Bu sınıflandırmaya göre BKİ'nin $18.50 \mathrm{~kg} / \mathrm{m}^{2}$ ve altı zayıf,

Tablo 1. BKI’nin sınıflandırılması (9).

\begin{tabular}{lc}
\hline Sınıflandırma & BKİ $\left(\mathbf{k g} / \mathbf{m}^{2}\right)$ \\
\hline Zayıf & $<18.50$ \\
Aşırı zayıf & $<16.00$ \\
Orta zayıf & $16.00-16.99$ \\
Hafif zayıf & $17.00-18.49$ \\
Normal & $18.50-24.99$ \\
Hafif şişman/Fazla kilolu & $\geq 25.00$ \\
Şişmanlı öncesi & $25.00-29.99$ \\
Şişman/Obez & $\geq 30.00$ \\
1. derece şişman & $30.00-34.99$ \\
2. derece şişman & $35.00-39.99$ \\
3. derece şişman (morbid) & $\geq 40.00$ \\
\hline
\end{tabular}

*BKi: Beden kitle indeksi 
$18.50-24.99 \mathrm{~kg} / \mathrm{m}^{2}$ arası normal ağırlık, 25.00-29.99 kg/ $\mathrm{m}^{2}$ arası fazla kilolu ve $30.00 \mathrm{~g} / \mathrm{m}^{2}$ ve üzeri obez olarak kabul edilmektedir (Tablo 1).

Obezite; birçok nedene bağlı olarak ortaya çıkan kompleks ve kronik bir hastalıktır. Obeziteye neden olan ana etmenin enerji alımı ve harcanması arasındaki dengesizlik olduğu literatürce kabul edilmiş bir gerçektir (10). Obezitenin nedenleri; çevresel, genetik, hormonal, metabolik ve farmakolojik olarak sinıflandırılabilir $(11,12)$. Aile yaşantısı, kültür, sosyoekonomik-sosyokültürel düzey düşüklüğü, yaş, cinsiyet, sigara kullanımı, ilaçlar, endokrin bozukluklar ve en önemlisi sedanter yaşamın benimsenmesi ve diyet kompozisyonunun sağlıksız oluşu obeziteyi tetikleyen en önemli çevresel faktörler arasında sayllabilir $(13,14)$. Vücut ağırlı̆̆ı kazanımı genetik faktörlerle de ilişkili bulunmaktadır (11). Evlat edinilen çocuklar üzerinde yapılan bir araştırmada çocukların BKİ değerlerinin biyolojik olmayan anne babalarına göre, biyolojik anne babalarıyla daha fazla benzerlik gösterdiği saptanmıştır (15). Kalıtımın obezite üzerindeki etkisinin yaklaşık \%30-70 civarında olduğu tahmin edilmektedir. Fakat bireyler uygun beslenme düzeni ve fiziksel aktiviteyle bu durumun etkilerinden kaçınabileceklerdir $(10,11,16)$. Hormonal bozukluklar ve çeşitli ilaçların kullanımı da sekonder obeziteye neden olan etmenler arasında gösterilmektedir (12). Obezitenin hipertansiyon, ateroskleroz gibi kardiyovasküler rahatsızlıkların; osteoartrit, gut gibi müsklosketal sitem rahatsılılılarının, renal bozuklukların, metabolik sendromun ve tip 2 diabetes mellitus (DM) prevalansının artışıla yakından ilişkili bildirilmektedir $(17,18,19)$. Hormonal ve genetik değişimler sonucunda; polikistik over sendromu, fertilite ve libidoda azalma, meme ve over kanserlerinde artış obezitenin neden olduğu diğer sağlık sorunlarıdır. Reflü, safta taşı ve hepatit obezitenin gastrointestinal sistem üzerindeki olumsuz etkileridir. Obezitenin getirdiği psikososyal durum rahatsızlıkları ise; özgüvende azalma, özsaygı yitimi, sosyal izolasyon, depresyon şeklinde özetlenebilir (17). Ayrıca obezite ile birlikte aşırı yağ birikiminin oksidatif strese ve bunun sonucunda da deoksiribonükleik asit (DNA) hasarına neden olduğu bildirilmiştir. Artan hasarlanmış DNA'lar ise vücutta kanser gelişimi ile ilişkilendirilmektedir (20).

\section{Obezitenin Tedavisi}

Obezite tedavisi medikal ve cerrahi tedavi olmak üzere ikiye ayrılmaktadır. Medikal tedavi fiziksel aktivite eşliğinde yaşam biçimini ve sağlıksız davranışları değiştirmeyi amaçlayan sürdürülebilir bir diyet tedavisini ve farmakolojik tedaviyi içermektedir. Medikal tedavinin sonuç vermediği durumlarda ise bariatrik cerrahiye başvurulmaktadır $(5,6)$.

\section{Bariatrik Cerrahi}

Bariatrik kelimesi köken olarak Yunanca kilo anlamina gelen "-bar" ve tedavi anlamina gelen “-iatria” kelimelerinin birleşmesiyle ortaya çıkmıştır (21). Bariatrik cerrahi ilk olarak 1950’lerin başında Dr. Richard Varco tarafindan muhtemelen vücut ağırlığı kaybına neden olması için malabsorbtif yöntemlerin atası olan Jejunoileal Bypass (JIB) şeklinde uygulanmış, 1954'te bu olgu Kremen ve Linner tarafından rapor olarak yayınlanmıştır $(21,22)$. Devam eden süreçte laparoskopi ve endoskopinin gelişmesiyle çeşitlendirilmiştir (23).

Bariatrik cerrahi yöntemleri; besin ögesi emilimini engelleyici (malabsorbtif) ve besin alımını kısıtlayıcı (restriktif) olmak üzere iki temel sınıfta incelenebilir. Ayrica hem malabsorbsiyona neden olan hem de besin alımını kısıtlayan kombine yöntemler de vardır (5,6,7). Restriktif yöntemler; İntragastrik Balon (IGB), Gastrik Stimülasyon (GS), Vertikal Band Gastroplasti (VBG), Laparoskopik Ayarlanabilir Gastrik Band (LAGB), Laparoskopik Sleeve Gastrektomi (LSG) (Tüp Mide)'dir. Malabsorbtif yöntemler; Biliopankreatik Diversiyon (BPD), Jejunoileal Bypass ve kombine yöntemler; Biliopankreatik Diversiyon-Duedonal Switch (BPD-DS), Roux en Y Gastrik Bypass (RYGB) ve Mini Gastrik Bypass (MGB)'dır (6,7,24).

Günümüzde uygulanan bariatrik cerrahinin başarısı postoperatif dönemde fazla olan vücut ağırlığındaki 
kayıp durumuna göre belirlenmektedir (25). Postoperatif dönemde hastaların fazla olan vücut ağırlığında \%40 ve daha az oranda kayıp olması durumunda ameliyat başarısız, \%40-60 aralığında kayıp olması durumunda orta düzeyde başarılı, $\% 60$ ve üzerinde kayıp olması durumunda ise iyi düzeyde başarılı olarak kabul edilir (6). Türkiye Endokrinoloji ve Metabolizma Derneği (TEMD) 2019 Obezite Tanı ve Tedavi Kılavuzu'na göre en sık kullanılan ve standart olarak kabul edilmiş yöntemler; LAGB, LSG, BPD-DS ve RYGB'dir ve bariatrik cerrahiye bağlı mortalite oranı yaklaşık \%1'dir (8). Fakat LAGB uygulama sıklığının son zamanlarda eskiye göre belirgin şekilde azaldığı bildirilmiştir (24).

Bariatrik cerrahi yöntemlerinin endikasyonları; BKI $>40 \mathrm{~kg} / \mathrm{m}^{2}$ olması ya da $\mathrm{BKI}>35 \mathrm{~kg} / \mathrm{m}^{2}$ beraberinde, tip 2 DM, hipertansiyon, uyku apnesi, hiperlipidemi, reflü gibi komorbidite varlığı, cerrahi öncesi medikal tedavilerde başarısız olunması, psikolojik durumun stabil olması, aile ve çevre desteğinin yerinde olması, alkol ve madde bağımlılığının olmaması, hastanın yapılacak uygulama hakkında tam bilgi sahibi olması şeklinde sıralanmaktadır (26).

\section{Preoperatif Dönemde Beslenme}

$\mathrm{Bu}$ dönemde uygulanacak beslenme takibi için bir standart yokken ilk olarak 2008 yllında Amerikan Metabolik ve Bariatrik Cerrahi Derneği (ASMBS) tarafından yayımlanan rehber bu konuya belirli bir standart getirmeye çalışmış, bu rehber son olarak 2016 yılında güncellenmiştir (27). Bu rehbere göre; preoperatif dönemde ilk basamakta yapılması gereken şey; hastaların ayrıntılı beslenme durumunun saptanmasıdır. Alkol kullanımları, günlük enerji alımları, günlük diyet kompozisyonları, beslenme alışkanlıkları, fiziksel aktivite durumu, klinik laboratuvar ve antropometrik değerlendirmeleri kayıt altına alınmalıdır. İkinci basamakta hastalara verilecek beslenme eğitimi planlanmalı ve uygulanmalıdır. Üçüncü basamakta postoperatif beslenme durumu takibinin ve gerekli diyet düzenlemelerinin yapılması, dördüncü basamakta biyokimyasal verilerin düzenli takibi ve beşinci basamakta vitamin-mineral takviyesinin sağlanması gelmektedir (28).

Preoperatif dönemde hastaların yüksek enerji almalarına rağmen ciddi mikro-makro/besin ögesi eksikliklerinin olabileceği unutulmamalıdır. Bariatrik cerrahi adaylarının \%35-80'i 'Yüksek Kalorili Malnütrisyon' durumundadır. Başta D vitamini, demir, $\mathrm{B}_{12}$ ve folat olmak üzere birçok mikro besin ögesi yetersizliği görülebilmektedir $(16,29,30)$. Bu dönemde hastalara sağlıklı beslenme programları verilerek eksik kalan mikro besin ögesi açıklarının kapatılması gerekir (31). Bu şekilde sağlıklı beslenme alışkanlıklarının kazandırılması da amaçlanır çünkü bu hastalar postoperatif dönemde sağlıklı beslenmeye uyum sorunu yaşayabilmektedir $(16,17)$. Ayrıca hastalara operasyondan en az 6 ay önce eğer kullanıyorlarsa sigarayı bırakmaları önerilmelidir (32).

Bariatrik cerrahide beslenme politikası konusunda ikilemler sürse de genel bir uygulama olarak cerrahi öncesivücutağırlığıverimisağlanmayaçalışılmaktadır. $\mathrm{Bu}$ nedenle ameliyat öncesi iki-dört hafta boyunca çok düşük enerjili diyetler uygulanır (16,29,30). Cerrahi öncesi uygulanan bu diyet programları karaciğerin küçülmesine yardımcı olmaktadır. Karaciğerin küçülmesi, fazla vücut ağırlığının ön kaybını sağlamakla birlikte karaciğerde biriken fazla yağ ve karbonhidratın eritilmesini, operasyon sırasında karaciğere bağlı gelişen komplikasyonların en aza indirilmesini ve glisemik kontrolü sağlamak için oldukça gereklidir (30). Cerrahi öncesi dönemde vücut ağırlığı kaybı hastaların ameliyat süresi ve komplikasyonlarını azaltmakta, hastanede yatış süresini de kısaltmaktadır (25). Bu dönemde diyetisyen tarafından hastalara gereksinimlerine göre düşük enerjili, düşük karbonhidratlı ve yeterli protein ihtiyacını karşılayacak şekilde bir diyet programı ayarlanmalıdır. Fakat bu dönemde ani hipoglisemi riskini engellemek için özellikle diyabetik hastalarda kan şekeri takibi yapılmalıdır (30). İkinci basamakta hastalara verilecek beslenme eğitimi operasyon başarısını artırmak adına çok önemlidir (29). 


\section{Postoperatif Dönemde Beslenme}

Operasyon sonrası beslenmede ilk olarak; dumping sendromunun, reflünün veya çok erken doygunluk hissinin oluşmaması için aşamalı ve sağlıklı diyetlerin planlanması, ikincil olarak ise hızlı iyileşmenin gerçekleşmesi; kas kütlesi kaybının ve eksikliklerin önüne geçmek için yeterli proteinin ve yeterli hidrasyonun sağlanması amaçlanmalıdır $(16,29)$. Amerikan Endokrin Topluluğu, Bariatrik Cerrahi Hastalarında Postoperatif Beslenme ve Endokrin Yönetimi Kılavuzu (33); postoperatif uzun dönemde yağsız vücut kütlesini koruyabilmek için uygulama fark etmeksizin tüm hastaların diyetlerinin 60-120 g/gün protein içermesini önermektedir. Bariatrik cerrahinin türü ne olursa olsun operasyon sonrası dönemde tüm hasta diyetlerine; ameliyat öncesi ve sonrası kan parametreleri, beslenme davranışları, besin toleransları, sınırlı besin alımları gibi durumlar göz önünde bulundurularak seçilecek vitaminmineral destekleri eklenmeli ve ömür boyu takibi sürdürülmelidir $(30,33)$.

Postoperatif dönemde oral veya enteral beslenmeye geçmeden önce anastomoz kaçağı oluşumunu engellemek için yutma testi yapılır. Bu türden sızıntılar genelde ilk 5 günde klasik iskemiye bağlı olarakgörülür (34). Fakat geç dönemde 6-12 hafta arasında ve kronik olarak 12. haftadan sonra da görülebilmektedir (24). Amerikan Klinik Endokrinologlar Topluluğu, Obezite Topluluğu ve Amerikan Metabolik ve Bariatrik Cerrahi Topluluğu'nun yayınlamış olduğu; 'Bariatrik Cerrahi Hastaları İçin Perioperatif Dönem Beslenme ve Metabolik Destek Rehberi'nde, tüm hastaların oral alıma başladıktan sonra ilk önce az miktarda (30 mL veya daha az) berrak sivilar yudumlamaları, yudumlanan sıvılar tamamen tolere edilebildiğinde ise anastomoza, kusmaya veya ameliyat bölgesinde hasara yol açmaması için ilk günden birkaç aya kadar yoğunluğu kademe kademe artan diyetlere yönlendirilmeleri gerektiği vurgulanmaktadır $(30,31,33)$. Aşamalar arasında geçiş süresi hastaların tolere edebilme kabiliyetlerine bağlıdır ve kişiden kişiye göre değişiklikgösterir (29). Parenteralbeslenme ise 5-7 veya 7-10 gün yeterli enteral beslenmeyi tolere edemeyen kritik hastalarda düşünülmelidir $(31,35)$. $\mathrm{Bu}$ dönemde diyetisyen kontrolünün ve beslenme programina yapılan müdahalelerin sıklıkla birinci ve ikinci haftada, ardından, birinci, ikinci, üçüncü, altıncı ve dokuzuncu ayda yapıldığı bildirilmiştir (28). Yoğunluğu giderek artan diyet evreleri aşağıda siralanmıştır.

Birinci evre (Açık sıvı diyet): Ameliyat sonrası ilk bağırsak hareketlerinin sağlanabilmesi için saat başı hastaya 120-180 mL berrak sıvıların verildiği evredir. Hastanın toleransina göre bu sıklık $30 \mathrm{~mL} / 15 \mathrm{dk}$ veya $60 \mathrm{~mL} / 30 \mathrm{dk}$ şeklinde de düzenlenebilir (29). Tüketilen sıvıların toplamının günlük en az 1.5 litreyi bulması amaçlanmalıdır. Bu berrak sıvılara; su, berrak çorbalar, bulyon suları, şekersiz jelatin, şekersiz meyve suları örnek verilebilir (36). Hastalar kesinlikle şeker içeren sıvıları tüketmemelidir (31). Tüketilen sıvıların çok soğuk veya çok sıcak olmayacak şekilde vücut ısısına yakın ısılarda olması önemlidir. Genelde ilk 48 saatte uygulanan bu diyet hastanin tolere edebilmesine göre daha uzun veya daha kısa süreli olabilir $(28,35)$.

İkinci evre (Yüksek proteinli tam sıvı diyet): $\mathrm{Bu}$ diyet postoperatif 2. veya 3. gün başlar ve 1012 gün sürer fakat hastanın tolerasyon durumuna göre kısaltılıp uzatılabilir (28). Bu evrede hastalar tarafından günlük alınan enerji 500-600 kkal civarında olmalıdır (36). Hastaların günde 1440-1920 $\mathrm{mL}$ sıvı tüketmelerine izin verilir. Bu sıvının yarısı açık sıvı diyet içeriğinden gelirken diğer yarısını tam sıvı diyet içeriği oluşturur (31). Hastaların diyetine açık sıvı diyet içeriğine ek olarak; sade yoğurt, yüksek proteinli düşük yağlı düşük karbonhidratlı içecekler, şekersiz elma suyu veya üzüm suyu, protein tozuyla karıştırılmış soya sütü ve peynir altı suyu veya soya proteini ile hazırlanmış yağsız süt (yağ oranı \%1) eklenir $(16,28,36)$. Hastalar bu orandan daha yüksek oranlarda (yağ oranı 22 ) yarım yağlı veya tam yağlı süt tüketmemelidir (29). Günde 6-8 öğün şeklinde beslenilmeye başlanmalı tolerasyon durumuna göre her öğünde tüketilen besin miktarı artırılmalıdır. Günlük diyet ortalama 60-80 gr protein içermelidir (37). Bu hedefe varılamadığı durumlarda endüstriyel 
modüler protein ürünleri kullanılabilir (16).

Üçüncü evre (Püre kıvamda yüksek proteinli diyetpüre diyeti): $\mathrm{Bu}$ diyetin uygulanması postoperatif ikinci haftadan altincı haftaya kadar uzanabilir (16,31). 10-14. günlerde berrak sıvı alımını artırmak (toplam sıvı alımı en az $\geq 1440-1920 \mathrm{~mL}$ olmalıdır) ve tam sıvıları püre kıvamındaki yumuşak, nemli, doğranmış veya öğütülmüş düşük yağlı ve yüksek proteinli yiyeceklerle değiştirmek gerekmektedir $(29,36)$. Bu yiyecekler arasinda; yumurta beyazl, kıyılmış kırmızı-beyaz et, yağsız soslar, et suyu ve bulyonlar, pişmiş fasulye, az yağlı peynir ve yoğurt sayllabilir $(16,28,36)$. Püre ve yarı katı yemeklerden 30 dakika önce sıvı alımı durdurulmalı, öğün sırasında veya öğünden 30 dakika sonrasına kadar sıvı tüketilmemelidir (37). Birinci ayın sonunda eğer protein içeriği yüksek gıdalar iyi tolere edilebilmişse iyi pişmiş yumuşak sebzeler ve gaz yapmaması için kabuğu soyulmuş meyveler diyete eklenmelidir $(31,37)$. Beşinci haftada ise bazı hastaların salatayı (yeşil ve çoban salata) tolere edebildiği görülmüştür bu nedenle tolerasyon durumuna göre dördüncü hafta diyetine ek olarak salata verilebilir (16,31). Bu evrede hastalar tarafından alınan enerji günlük 500-700 kkal; protein ise günlük 50-70 g civarında olmalıdır (36).

Dördüncü evre (Yumuşak diyet): Yumuşak diyet normal katı diyete geçişte bir basamak olarak kullanılmaktadır $(28,29)$. Bu evrede püre diyete ek olarak düşük karbonhidratlı tahıllar, makarna, yulaf ezmesi, pirinç pilavı, patates püresi, tost, taze pişmiş sebzeler, kabuğu soyulmuş yumuşak az şekerli meyveler eklenebilmektedir (36,37). Hastalar ilk önce tabaklarındaki protein içeriği yüksek besinleri tüketmelidir ve ortalama günlük $60 \mathrm{~g}$ protein almadan karbonhidrat içeriği yüksek olan pilav makarna gibi gıdalardan kaçınmalıdırlar (31,37). Bu evrede berrak sıvı alımı 1440-1920 mL'ye çıkarılmalıdır (29). Hastalar tarafından alınan enerji günlük 700-800 kkal olmalı ve hastalar günde 3-6 öğün şeklinde beslenmelidir (36).

Beşinci evre (Katı diyet): Katı diyet evresi RYGB uygulamasında 8. haftaya uzayan, diğer evrelerde genelde 6. haftadan itibaren başlayan evredir (29). Bu evrede her türlü besin grubundan dengeli ve yeterli bir şekilde içeren sağlıklı beslenme diyetlerine geçilir ve yaşam boyunca sürmesi planlanır $(16,36)$. Hastalar bu evrede, çeşitli besinlere karşı intolerans geliştirme riskleri olduğundan dolayı; kızartılmış besinlerden, kurutulmuş meyvelerden, meyve tohumlarından, findıklı tatlılardan, reçellerden, şekerli marmelatlardan, sakızlardan uzak tutulmalıdır (37). $\mathrm{Bu}$ aşamada hastalara sağlıklı yaşam önerileri verilir (31).

\section{Kısa Dönem Komplikasyonları}

Cerrahi sonrası kısa dönem komplikasyonları bulantı, kusma, dehidratasyon, diyare, konstipasyon, besin intoleransları ve dumping sendromudur. Bulantı ve kusma genelde tüm hastalarda aşırı yemek yemeye çalışmak ve yiyeceklerin büyük miktarlarda yutulması sonucu görülür. Sık kusmalar ve besin alımının azalması dehidratasyonla sonuçlanabilir. $\mathrm{Bu}$ yüzden hastalara az az, sık sık, küçük lokmaları çok çiğneyerek yemek yemek, gün içinde tek seferde fazla miktarda sıvı alımı yerine, yudum yudum (30'ar mL) su içmek ve su içmek için susamayl beklememek önerilmektedir $(16,37,38)$. Konstipasyon ve diyare durumunda diyet lif oranı tekrar gözden geçirilmelidir (30). Besin intoleransı özellikle kuru, sakızımsı, lifli gıdalarda, dana eti gibi kırmızı etlerde, çiğ sebzelerde görülebilir. Hastalara diyetlerine her seferinde yeni bir yiyecek eklemeleri, bu süreçte tolerans gösteremedikleri yiyecekleri tüketmemeleri önerilmektedir. Aşırı şekerli ve yağlı yiyecekler dumping sendromunu tetiklediği için hastaların diyetlerinde bu türden gidalara sinırlama ya da yasak getirilmektedir $(16,33,36)$.

\section{Uzun Dönem Komplikasyonları}

Diyete bağlı uzun dönem komplikasyonları genelde; protein ve yağ gibi makro; vitamin-mineraller gibi mikro besin ögesi yetersizlikleri ve enerji yetersizlikleridir (16,36). Ameliyattan sonra çeşitli nedenlerden kaynaklanan yetersiz protein ve enerji alımı, besin ögelerinin yetersiz emilimi gibi nedenlerden protein-enerji malnutrisyonu 
(PEM) sık görülen komplikasyonlardandır. PEM vakalarının önüne geçebilmek adına hastaların kan proteinleri özellikle de serum prealbumini incelenmeli, hastaların protein alımı yeniden gözden geçirilmelidir $(16,38,39)$. Yağ malabsorbsiyonları da genelde sıklıkla malabsorbtif operasyonlarda gözlenir ve uzun dönemde yağda eriyen vitamin (A, D, E, K) eksikliklerine neden olur (16,33). Vitamin ve mineral eksiklikleri postoperatif dönemde birçok hastanın porsiyon boyutları anlamlı şekilde azaldığı, özellikle kırmızı et ve çiğ sebzelere karşı besin intoleransları gelişebildiği ve kusma-bulantı durumları sıklaştığı için tüm cerrahi türlerinde gözlenmektedir. Ameliyat sonrasında başta demir, $\mathrm{B}_{1}, \mathrm{~B}_{6}, \mathrm{~B}_{9}, \mathrm{~B}_{12}$, D vitamini, A vitamini, E vitamini, kalsiyum, magnezyum, çinko, bakır olmak üzere kapsamlı vitamin-mineral desteği son derece önemlidir $(16,38)$. Bazı besin ögeleri intestinal kanalda belirli bölgelerde daha çok emilirler. Özellikle malabsorbtif operasyonlarda operasyonun türüne göre ortaya çıkacak olan makro ve mikro besin ögesi yetersizlikleri bu verilerden yola çıkılarak öngörülebilir (38). Bu emilim bölgeleri Tablo 2'de gösterilmiştir. Cerrahi sonrası karşılaşılabilen bir başka uzun dönem komplikasyonu da tekrar vücut ağırlığı kazanımıdır. Özellikle ameliyattan sonraki 2-5 yılları arasında tekrar vücut ağırlığı kazanımı riski yüksektir. Gece yeme, duygusal yeme, depresyon ve yeme endişesi durumu yaşayan hastaların tekrar vücut ağırlı̆̆ı kazanım oranlarının diğer hastalara göre daha yüksek olduğu bildirilmiştir (40).

\section{Tıbbi Beslenme Tedavisinde Öneriler}

Hastalar tokluk hissi sağlaması ve bulantıkusmayı engellemesi için öğünlerini en az 20 dakikada tüketmelidirler. Özellikle mide hacminin küçültüldüğü operasyonlar sonrasında küçük lokmalar tüketmek ve uzun süre çiğnemek olası tıkanıklıkları engelleyecektir. Günde 3-6 öğün şeklinde beslenilmelidir. Öğün atlanmamalıdır ve öğün saatleri düzenli olmalıdır. Öğün atlandığı durumlarda, bir sonraki öğünde protein eksikliğinin önüne geçmek için özellikle protein açı̆̆ını kapatmak gerekmektedir. Olası protein malnütrisyonu riskinin

Tablo 2. İntestinal yolda bazı mikro besin ögelerinin yoğun emilim gösterdiği bölgeler (38).

\begin{tabular}{|c|c|c|c|}
\hline Mide & Duedonum & Jejunum & İleum \\
\hline $\mathrm{Su}$ & Kalsiyum & Tiamin & Askorbik asit \\
\hline Etil alkol & Demir & Riboflavin & Folat \\
\hline Bakır & Potasyum & Niasin & Kobalamin \\
\hline İyot & Magnezyum & Pantotenik asit & D vit. \\
\hline Flor & Bakir & Biotin & K vit. \\
\hline Molibden & Selenyum & Folat & Magnezyum \\
\hline \multirow[t]{14}{*}{ İntrinsik faktör } & Tiamin & Piridoksin & Safra tuzu /Asitler \\
\hline & Riboflavin & Askorbik asit & \\
\hline & Niasin & $\mathrm{A}, \mathrm{D}, \mathrm{E}, \mathrm{K}$ & \\
\hline & Biotin & Dipeptitler & \\
\hline & Folat & Tripeptitler & \\
\hline & $\mathrm{A}, \mathrm{D}, \mathrm{E}, \mathrm{K}$ & Kalsiyum & \\
\hline & & Demir & \\
\hline & & Potasyum & \\
\hline & & Magnezyum & \\
\hline & & Çinko & \\
\hline & & Krom & \\
\hline & & Manganez & \\
\hline & & Molibden & \\
\hline & & Aminoasitler & \\
\hline
\end{tabular}


önüne geçmek için proteinler, karbonhidratlardan ve yağlardan önce tüketilmelidir $(16,30)$. Çay, kahve, kola gibi kafeinli ve asitli içecekler dehidratasyona neden olduğu için sinırlandırılmalıdır. Yiyeceklerin çok lifli olması, sakız gibi yapışkan olması veya çok kuru olması ağrıya neden olabileceğinden bu tür besinler kontrollü tüketilmelidir. Fazla miktarlarda şeker tüketmek belirtileri mide bulantısı, mide ağrısı, kusma, diyare, taşikardi, terleme olan dumping sendromunu tetiklediği için, şeker içerikli gıdalardan kaçınılmalı, basit karbonhidratlar yerine kompleks karbonhidratlar tercih edilmelidir $(16,30,33)$. Hastaların diyetlerinden tatlılar, şekerler, çikolata, karbonatlı içecekler, reçel, bal, jöleli tatlılar çıkartılmalıdır. Hastalar yemeklerden 30 dakika önce ve sonra su veya sıvı besinleri tüketmemelidirler. Kusma ve diyarenin önüne geçmekve alınmasıgereken katı besinlerin eksiksiz olarak tüketilebilmesi için su ve sıvı besinler yemek sırasında da tüketilmemelidir $(30,33)$. Doygunluk hissedildiği zaman yeme içme sonlandırılmalıdır. Hastalar enerjisi fazla olup besleyiciliği düşük olan besinler yerine enerjisi düşük besleyiciliği fazla olan besinlere yönlendirilmelidir. Her gün en az 30 dakika aerobik fiziksel aktivite yapılmalıdır. Hafif adımlama, merdiven inip çıkma gibi hafif egzersizlerden başlayarak yoğun aerobik egzersizlere gidilmelidir (16,32).

\section{SONUÇ VE ÖNERILER}

Obezitenin tedavisinde medikal tedavilerin sonuç vermediği hastalarda çeşitli endikasyonlar çerçevesinde uygulanan bariatrik cerrahinin besin alımını kısıtlayıcı, besin ögesi emilimini engelleyici ve kombine yöntemleri mevcuttur. Bariatrik cerrahide mortalite oranının yaklaşık \%1 olduğu belirtilmektedir. Başarı oranı ise operasyon sonrasındaki kilo kayı oranı ile belirlenmektedir. Çeşitli kısa ve uzun dönem komplikasyonları bulunan bariatrik cerrahi sürecinde komplikasyon risklerinin önüne geçebilmek ve operasyonun başarı oranını en üst seviyede tutabilmek açısından uygulanacak tıbbi beslenme tedavisi son derece önemlidir. Literatürde vurgulanan ilke ve önerilerin hastaların sağlıklı beslenme programları oluşturulurken dikkate alınması ve devam eden süreçte hastaların beslenme takibinin dikkatle yapılması konusunda diyetisyenlere büyük görev ve sorumluluklar düşmektedir.

Çıkar çatışması - Conflict of interest: Yazarlar çıkar çatışması olmadığını beyan ederler. - The authors declare that they have no conflict of interest.

\section{KAYNAKLAR}

1. World Health Organization. Body mass index classification 2018. Available at: http://www. assessmentpsychology.com/icbmi.htm. Accessed September 30, 2019.

2. Türkiye Nüfus ve Sağlık Araştırmaları 2013. Erişim: https://www.tuseb.gov.tr/enstitu/tacese/t-rkiye-n-fus-vesa-l-k-ara-t-rmalar-tnsa. Erişim Tarihi: 30 Eylül 2019.

3. Sağlik Bakanlığı. Türkiye Beslenme ve Sağlık Araştırması 2010, Ankara: Sağlik Bakanlığı Yayınları; 2014. ss 608. Rapor No: 931.

4. World Health Organization. Obesity. 2006. Available at: https://www.who.int/topics/obesity/en/. Accessed September 30, 2019.

5. Dizlek D, Çatal E. Morbid obezitede bariatrik cerrahi sonrası hasta sonuçları. DÜBİTED. 2018;6(2):501-12.

6. Korkmaz MF. Bariatrik cerrahinin morbid obez bireylerde total antioksidan kapasite üzerine etkisi [Uzmanlık Tezi]. Firat Üniversitesi Tıp Fakültesi, Elazığ; 2018.

7. Aydın E, Bulut H. Bariatrik Cerrahide Hemşirelik Bakımı. TAF Prev Med Bull. 2014;13(1):77-82.

8. Türkiye Endokrinoloji ve Metabolizma Derneği. Obezite Tanı ve Tedavi Kılavuzu. Ankara: 2019.

9. World Health Organization. Global health observatory data 2016. Available at: https://www.who.int/gho/en/. Accessed September 30, 2019.

10. Baysal A, Aksoy M, Besler T, Bozkurt N, Keçecioğlu S, Mercanlıgil S, ve ark. Diyet el kitabı. Yedinci Baskı. Ankara: Hatiboğlu Yayınları; 2013. ss 650.

11. Gürel SF, İnan G. Çocukluk çağı obezitesi tanı yöntemleri, prevalansı ve etyolojisi. ADÜ Tıp Fakültesi Dergisi.2001;2(3):39-46.

12. Alpcan A, Durmaz ŞA. Çağımızın dev sorunu: çocukluk çağı obezitesi. Turk J Clin Lab. 2015;6(1):30-8.

13. İlhan BÖ. Obezite cerrahisinin benlik saygisı ve yaşam kalitesine etkisi [Yüksek Lisans Tezi]. Maltepe Üniversitesi Sağlık Bilimleri Enstitüsü, İstanbul; 2018.

14. Baltacı G. Obezite ve egzersiz [İnternet]. Ankara: Sağlık Bakanlığı Yayınları; 2008. ss 20. Erişim: https://sbu. 
saglik.gov.tr/Ekutuphane/kitaplar/t37.pdf

15. Stunkard AJ, Sørensen TIA, Hanis C, Teasdale TW, Chakraborty R, Schull WJ, et al. An adoption study of human obesity. N Engl J Med. 1986;314(4):193-8.

16. Alphan MET, Baş M, Baysal A, Kutluay TM, Kızıltan G, Pekcan G. Hastalıklarda beslenme tedavisi. İkinci Baskı. Alphan MET, editör. Ankara: Hatiboğlu Yayınları; 2014. ss 1045.

17. Serter R. Obezite atlası. Ankara: Karakter Color Basımevi; 2004. ss 136.

18. Açlkgöz AÖ. Morbid obezite cerrahisi geçiren hastalarda zor havayolu insidansı ve eşlik eden hastalıklar [Uzmanlık Tezi]. Hacettepe Üniversitesi Tıp Fakültesi, Ankara; 2014.

19. Karthikeyan G, Nataraj M. Microalbuminuria among obese and non-obese individuals: a case control study. Int J Adv Med. 2019;6(3):717-21.

20. Włodarczyk M, Nowicka G. Obesity, DNA damage, and development of obesity-related diseases. Int J Mol Sci. 2019;20(5):1-18.

21. Deveci E. Obezite cerrahisi adayı olan ve olmayan obez bireylerde yeme özellikleri, beden bölgesinden hoşnutsuzluk, tedavi motivasyonu ve psikopatolojinin değerlendirilmesi [Yüksek Lisans Tezi]. İstanbul Üniversitesi Sosyal Bilimler Enstitüsü, İstanbul; 2013.

22. Buchwald H. Buchwald's atlas of metabolic and bariatric surgical techniques and procedures. Filedelfiya: Elsevier; 2011.

23. Buchwald H, Buchwald JN. Evolution of operative procedures for the management of morbid obesity 1950-2000. Obes Surg. 2002;12(5):705-17.

24. Sağlam F, Güven H. Obezitenin cerrahi tedavisi. Okmeydanı Tıp Dergisi. 2014;30(1):60-5.

25. Türkiye Endokrinoloji ve Metabolizma Derneği. Bariyatrik Cerrahi Kılavuzu. Ankara: 2019.

26. Hubbard VS, Hall WH. National institutes of health consensus development conference draft statement. gastrointestinal surgery for severe obesity. Obes Surg. 1991;1:257-65.

27. Parrott J, Frank L, Rabena R, Craggs-Dino L, Isom KA, Greiman L. American society for metabolic and bariatric surgery integrated health nutritional guidelines for the surgical weight loss patient 2016 update: micronutrients. SOARD. 2017;13(5):727-41.

28. Aills L, Blankenship J, Buffington C, Furtado M, Parrott J. ASMBS allied health nutritional guidelines for the surgical weight loss patient. SOARD. 2008;4(5):73-108.

29. Urhan M, Şanlıer N. Bariyatrik cerrahide beslenmenin önemi. Turkiye Klinikleri J Gastroenterohepatol. 2014;21(2):31-42.

30. Shannon C, Gervasoni A, Williams T. The bariatric surgery patient: nutrition considerations. Aust Fam Physician. 2013;42(8):547-52.

31. Mechanick J, Kushner R, Sugerman H, Campoy JG, Clavell MC, Guven S, et al. American association of clinical endocrinologists, the obesity society, and american society for metabolic and bariatric surgery medical guidelines for clinical practice for the perioperative nutritional, metabolic, and nonsurgical support of the bariatric surgery patient. Endocr Pract. 2008;14:1-83.

32. Güçlü A. Bariatrik cerrahi ve perioperatif hemşirelik bakimı. STED. 2018;27(3):209-11.

33. Heber D, Greenway FL, Kaplan LM, Livingston E, Salvador J, Still C. Endocrine and nutritional management of the post-bariatric surgery patient: an endocrine society clinical practice guideline. J Clin Endocrinol Metab. 2010;95(11):4823-43.

34. Baker RS, Foote J, Kemmeter P, Brady R, Vroegop T, Serveld M. The science of stapling and leaks. Obes Surg. 2004;14(10):1290-8.

35. Mechanick JI, Youdim A, Jones DB, Garvey WT, Hurley DL, McMahon MM, et al. Clinical practice guidelines for the perioperative nutritional, metabolic, and nonsurgical support of the bariatric surgery patient-2013 update: cosponsored by american association of clinical endocrinologists, the obesity society, and american society for metabolic and bariatric surgery. Obesity. 2013;21(1):1-27.

36. Fullmer MA, Abrams SH, Hrovat K, Mooney L, Scheimann AO, Hillman JB, et al. Nutritional strategy for adolescents undergoing bariatric surgery: report of a working group of the nutrition committee of naspghan/ nachri. J Pediatr Gastroenterol Nutr. 2012;54(1):125-35.

37. Grindel ME, Grindel CG. Nursing care of the person having bariatric surgery. Medsurg Nurs. 2006;15(3):129146.

38. Shikora SA, Kim JJ, Tarnoff ME. Nutrition and gastrointestinal complications of bariatric surgery. Nutr Clin Pract. 2007;22(1):29-40.

39. Faintuch J, Matsuda M, Cruz MELF, Silva MM, Teivelis MP, Garrido AB, et al. Severe protein-calorie malnutrition after bariatric procedures. Obes Surg. 2004;14(2):175-81.

40. Ünal Ş, Sevinçer GM, Maner AF. Bariatrik cerrahi sonrası kilo geri alımının; gece yeme, duygusal yeme, yeme endişesi, depresyon ve demografik özellikler tarafindan yordanması. Türk Psikiyatri Dergisi. 2019;30(1):31-41. 